\title{
Evaluating the effects of high-oil rapeseed cake or natural additives on methane emissions and performance of dairy cows
}

\author{
A. R. Bayat, ${ }^{1 *} \odot$ J. Vilkki, ${ }^{1} \oplus$ A. Razzaghi, ${ }^{1} \odot$ H. Leskinen, ${ }^{1} \odot$ H. Kettunen, ${ }^{2} \odot$ R. Khurana, ${ }^{3} \odot$ T. Brand, ${ }^{3}{ }^{\circ}$ \\ and S. Ahvenjärvi ${ }^{1}$ (1) \\ ${ }^{1}$ Production Systems, Natural Resources Institute Finland (Luke), Jokioinen 31600, Finland \\ ${ }^{2}$ Hankkija Oy, Peltokuumolantie 4, 05801 Hyvinkää, Finland \\ ${ }^{3}$ Mootral SA, Z.A. La Pièce 1 - A5, 1180 Rolle, Switzerland
}

\begin{abstract}
We evaluated the potential of feeding high-oil rapeseed cake or natural additives as rumen modifiers on enteric methane $\left(\mathrm{CH}_{4}\right)$ emissions, nutrient utilization, performance, and milk fatty acid (FA) profile of dairy cows. Eight Nordic Red dairy cows averaging (mean \pm SD) $81 \pm 21 \mathrm{~d}$ in milk and $41.0 \pm 1.9 \mathrm{~kg}$ of milk yield at the beginning of the study were randomly assigned to a replicated $4 \times 4$ Latin square design with 21 -d periods. Treatments comprised grass silage-based diets (45:55 forage to concentrate ratio on dry matter basis) including (1) control containing $19.3 \%$ rapeseed meal (CON), (2) CON with full replacement of rapeseed meal with rapeseed cake (RSC), (3) supplementation of CON with $50 \mathrm{~g} / \mathrm{d}$ of yeast hydrolysate product plus coniferous resin acid-based compound (YHR), and (4) supplementation of CON with $20 \mathrm{~g} / \mathrm{d}$ of combination of garlic-citrus extract and essential oils in a pellet (GCE). Apparent total-tract digestibility was measured using total collection of feces, and $\mathrm{CH}_{4}$ emissions were measured in respiratory chambers on 4 consecutive days. Data collected during d 17 and 21 in each period were used for ANOVA analysis using a mixed model. Treatments did not affect dry matter intake (DMI), whereas feeding RSC increased crude protein and ether extract digestibility compared with the other diets. Emissions of $\mathrm{CH}_{4}$ per day, per kilogram of DMI, and per kilogram of energy-corrected milk, and gross energy intake were lower for RSC compared with other diets. We found no effect of YHR on daily $\mathrm{CH}_{4}$ emissions, whereas $\mathrm{CH}_{4}$ yield ( $\mathrm{g}$ of $\mathrm{CH}_{4} / \mathrm{kg}$ of DMI or as percentage of gross energy intake) decreased with GCE compared with CON. Treatments did not influence energy balance. Further, RSC reduced the proportion of $\mathrm{N}$ intake excreted in feces, and YHR improved $\mathrm{N}$ balance compared with CON diet. Feeding RSC resulted in greatest yields of
\end{abstract}

Received March 29, 2021.

Accepted September 30, 2021.

*Corresponding author: alireza.bayat@luke.fi milk and energy-corrected milk, and feed efficiency. Relative to the CON diet, RSC decreased saturated FA by $10 \%$ in milk fat by increasing cis-monounsaturated FA but also increased the proportion of trans FA. Proportion of odd- and branched-chain FA increased with GCE and YHR compared with CON. We conclude that replacing rapeseed meal by rapeseed cake decreased $\mathrm{CH}_{4}$ emissions, whereas YHR or GCE had no effect on $\mathrm{CH}_{4}$ emissions in this study.

Key words: oil supplementation, natural additive, greenhouse gas, ruminant

\section{INTRODUCTION}

Meeting the need to feed the constantly growing human population without deleterious impact on the environment is a global challenge. Ruminants are an important part of the food system because of their ability to convert feedstuffs unsuitable for human consumption into high-quality protein in milk and meat. However, they also contribute to climate change, mainly by emitting methane $\left(\mathrm{CH}_{4}\right)$, a potent greenhouse gas, as a product of rumen fermentation. Methane also represents an estimated loss of $6.0 \pm 1.18 \%$ of energy intake from dairy cows (Niu et al., 2018). Although $\mathrm{CH}_{4}$ is a more potent greenhouse gas than $\mathrm{CO}_{2}$, it has a shorter lifetime (half-life of $8.6 \mathrm{yr}$; Muller and Muller, 2017) than $\mathrm{CO}_{2}$, which makes it an attractive target for quicker global warming abatement.

Current approaches to improve sustainability of ruminant production include breeding of animals with improved feed efficiency and reduced $\mathrm{CH}_{4}$ emissions (Beauchemin et al., 2020) as well as optimization of animal feeding and management. Several nutritional and management strategies have been reported to be effective in mitigation of greenhouse gas emissions from ruminants (Knapp et al., 2014; Beauchemin et al., 2020). Lipid supplementation is one of the most promising tools to depress $\mathrm{CH}_{4}$ production from ruminants (Beauchemin et al., 2009; Bayat et al., 2018). Dietary lipid supplements can also increase feed ef- 
ficiency (NRC, 2001) and increase the proportion of nutritionally desirable milk fatty acids (FA; Kliem and Shingfield, 2016; Kliem et al., 2019b). Previous studies have demonstrated reduced $\mathrm{CH}_{4}$ emissions per kilogram of feed intake by supplementing rapeseed cake as a practical means of introducing lipids to dairy cow diets without adversely affecting feed intake or performance (Brask et al., 2013a,b). It is expected that replacement of rapeseed meal with rapeseed cake reduces $\mathrm{CH}_{4}$ emissions, improves milk FA composition, and also may increase milk yield by providing additional oil to the diet.

Recently, increasing attention has been paid to the potential of chemical additives, such as 3-nitrooxypropanol and nitrate (Hristov et al., 2015), or plant extracts, such as tannins, saponins, and essential oils derived from garlic or oregano, in reducing $\mathrm{CH}_{4}$ emissions (Yang et al., 2007; Kolling et al., 2018; Olijhoek et al., 2019). Enteric $\mathrm{CH}_{4}$ reductions achieved in ruminants by different dietary strategies range from 0 to 80\% (Beauchemin et al., 2020). However, many of these strategies are not feasible solutions in practice, due to availability, transient effects, or high implementation costs.

In this study, we tested natural additives consisting of garlic (Allium sativum), citrus extracts (Citrus aurantium), and essential oils, which reduced ruminal $\mathrm{CH}_{4}$ production in an in vitro experiment by targeting methanogenic archaea (Eger et al., 2018). Roque et al. (2019) observed a $23 \%$ reduction in $\mathrm{CH}_{4}$ yield of Angus $\times$ Hereford crossbred steers fed $15 \mathrm{~g} / \mathrm{d}$ of a combination of garlic and citrus extracts without essential oils for $12 \mathrm{wk}$. We also tested another type of natural additive, a combination of yeast hydrolysate and a coniferous resin acid-based compound. A Saccharomyces cerevisiae yeast hydrolysate product increased microbial biomass and propionic acid production by rumen microbes in vitro (Kettunen et al., 2016). Furthermore, adding a resin acid-based compound (a by-product of wood processing industries, containing free FA and resin acids) has resulted in mild immunomodulatory effects and improved performance in dairy cows (Qin et al., 2020), pigs (Hasan et al., 2018a,b), and broiler chickens (Vienola et al., 2018). However, the effects of feeding these products as a combination to lactating dairy cows remain to be evaluated. We hypothesized that dietary supplementation of a resin acid-based compound and yeast hydrolysate in combination would have a synergistic effect in modulating rumen fermentation characteristics and $\mathrm{CH}_{4}$ production in lactating dairy cows.

The main objectives of the present study were to evaluate the potential of dietary treatments on reducing enteric $\mathrm{CH}_{4}$ emissions from dairy cows and to evalu- ate their influence on nutrient utilization, performance, and milk FA composition. The main hypotheses were that the high-oil rapeseed cake diet or dietary natural additives would reduce enteric $\mathrm{CH}_{4}$ emissions per unit of milk by altering rumen fermentation pattern without impairing animal performance and nutrient utilization. In addition, we hypothesized that the high-oil rapeseed cake would improve milk FA composition.

\section{MATERIALS AND METHODS}

\section{Animals, Experimental Design, and Diets}

The experiment was conducted under regional State Administrative Agency approval (Hämeenlinnan, Finland; ESAVI/34265/2019) in accordance with the guidelines established by the European Community Council Directive 2010/63/EU for animal experiments complying with the ARRIVE guidelines (Kilkenny et al., 2010). We performed sample size analysis based on the assumption of achieving $10 \%$ reduction in daily $\mathrm{CH}_{4}$ production as grams per day, when the power (1 $-\beta$ ) of the study is 0.85 and 0.90 and $\alpha$ is 0.05 in a one-sided test, which resulted in 7 or 9 replicates, respectively. Therefore, 8 multiparous Nordic Red dairy cows were randomly assigned to treatment sequences in a replicated $4 \times 4$ Latin square design to generate 8 experimental units (animal per period) for each treatment. The animals were distributed to squares to balance for differences in DIM, milk production, and parity, resulting in 2 squares (mean $\pm \mathrm{SD}$; square 1: 655 $\pm 33.0 \mathrm{~kg}$ of BW, $96 \pm 17.9 \mathrm{DIM}, 41.2 \pm 2.2 \mathrm{~kg}$ of milk per day, and parity $3.5 \pm 1.0$; square $2: 638 \pm 39.4 \mathrm{~kg}$ of BW, $65 \pm 9.4$ DIM, $41.2 \pm 1.9 \mathrm{~kg}$ of milk per day, and parity $3.5 \pm 1.3)$. The second square of cows entered the study 1 wk after the first-square cows. Each period lasted $21 \mathrm{~d}$, with $16 \mathrm{~d}$ for diet adaptation followed by 5 $\mathrm{d}$ for data and sample collection.

Cows received diets formulated to yield (on DM basis) a 45:55 ratio of grass silage to concentrate $(\mathbf{F}: \mathbf{C})$, composed of the following: (1) control, containing $19.3 \%$ rapeseed meal on DM basis (CON), (2) CON with full replacement of rapeseed meal with rapeseed cake (RSC; $19.3 \%$ DM), (3) CON supplemented with $20 \mathrm{~g} / \mathrm{d}$ of yeast hydrolysate product plus $30 \mathrm{~g} / \mathrm{d}$ of resin acid-based compound (YHR), and (4) CON supplemented with $20 \mathrm{~g} / \mathrm{d}$ of a combination of garlic-citrus extract and essential oils (GCE). The treatments were selected based on their potential to reduce enteric $\mathrm{CH}_{4}$ production. The doses of yeast hydrolysate product and resin acid-based compound were based on a previous ex vivo simulation experiment using rumen microbiota from lactating dairy cows (J. Apajalahti, T. Rinttilä, 
and H. Grönberg; Alimetrics Research Inc., Espoo, Finland; personal communication), resulting in a decrease in $\mathrm{CH}_{4}$ production. In our study, the amount of the yeast hydrolysate product used was 2-fold greater than the dosage recommended for improving the performance of dairy cows $(10 \mathrm{~g} / \mathrm{d})$. In previous experiments with lactating dairy cows, 0.63 to $0.90 \mathrm{~g} / \mathrm{d}$ of resin acids were fed per animal. In the present study, the daily dosage was $1.35 \mathrm{~g} / \mathrm{d}$ per cow. The doses were doubled to ensure the products' efficacy. The raw material for the resin acid-based compound originates from northern coniferous trees, Scots pine (Pinus sylvestris) and Norway spruce (Picea abies). The resin acid-based compound (powder form) in our study contained $40 \%$ free FA (consisting of $50-55 \%$ various linoleic acids, 25-30\% oleic acid, and 6-8\% pinolenic acid), 9\% resin acids in lipid soluble form (mainly abietic, dehydroabietic, and pimaric acid), 1\% unsaponifiable carrier, and $50 \%$ silicate carrier (Progres Dry, Hankkija Oy). The free-flowing yeast hydrolysate product contained $66 \%$ Saccharomyces cerevisiae, $14.5 \%$ sodium phosphates, $16.5 \%$ extracts from barley and barley malts, and 3\% anticaking agent sepiolite (Progut Rumen, Hankkija $\mathrm{Oy}$ ).

The additive GCE, fed at $20 \mathrm{~g} / \mathrm{d}$, consisted of a blend of garlic powder with allicin content $>1 \%$, extracts of citrus bioflavonoids (Citrus aurantium), and a mixture of essential oils, eugenol, and geranyl acetate (Mootral $\mathrm{SA}$ ), in a pellet formulation. The dosage was selected based on a previous in vivo trial (Vrancken et al., 2019), wherein a significant reduction in enteric $\mathrm{CH}_{4}$ emissions from dairy cows was observed at a similar dose. Ingredients and chemical composition of experimental diets are shown in Table 1. Forage (timothy and meadow fescue swards) was cut and field-wilted to about $30 \%$ DM and treated with a formic acid-based ensiling additive ( $5 \mathrm{~L} / \mathrm{t}, \mathrm{AIV}$ Ässä Na). The cows received forage at 0800, 1400, 1700, and $1900 \mathrm{~h}$, to ensure constant access to forage source. Grass silage and concentrates were fed separately, and the amount of silage and concentrates offered was adjusted individually based on the feed intake in the previous days, to maintain $\mathrm{F}$ : $\mathrm{C}$ ratio of 45:55. Supplemental concentrate pellets were fed at 0600, 0900, 1500, 1800, and $2000 \mathrm{~h}$. At $0600 \mathrm{~h}, 2.0 \mathrm{~kg}$ of pelleted CON concentrate mixed with garlic-citrus extract and essential oils was fed to GCE cows. According to the producer's instructions, the additive was fed once a day, and possible leftovers of the mixture were put on top of the morning silage portion to ensure complete consumption. To ensure similar conditions for all treatments, other cows received $2.0 \mathrm{~kg}$ of their respective concentrates at the same time $(0600 \mathrm{~h})$ without access to silage. For the YHR treatment, the yeast hydrolysate product and the resin acid-based compound were mixed with concentrate ingredients before preparing the pellet. Ten kilograms of this concentrate was fed in different portions during the day, to make sure that each cow received 20 and $30 \mathrm{~g} / \mathrm{d}$ of yeast hydrolysate product and resin acid-based compound per day, respectively. The rest of the concentrate needed for the cows on this treatment to achieve $\mathrm{F}: \mathrm{C}$ ratio of $45: 55$ was provided from control concentrate. For the RSC diet, cold-pressed rapeseed cake (Alavuden Öljynpuristamo Ltd.) with high residual oil content substituted rapeseed meal in CON. The CON concentrate $(600 \mathrm{~g} / \mathrm{d})$ was provided to all cows in the milking parlor, which was considered in the $\mathrm{F}$ :C ratio calculations. The amount of feed offered to the cows was adjusted daily to yield leftovers equal to 5 to $10 \%$ of DMI. The cows were housed in tiestalls with rubber mats and had free access to water and salt blocks during the adaptation period. The cows from each square entered the respiration chambers on $\mathrm{d} 17$ of each period for $\mathrm{CH}_{4}$ measurements and total fecal and urine collection for $4 \mathrm{~d}$, of which the first day served as acclimatization.

\section{Measurements and Chemical Analysis}

For accurate formulation of the experimental diets and to maintain the predetermined $\mathrm{F}: \mathrm{C}$ ratio, $\mathrm{DM}$ content of grass silage was analyzed every week during the experiment at $105^{\circ} \mathrm{C}$ for $20 \mathrm{~h}$ in a forced-air oven. Representative samples of grass silage and concentrate pellets were collected from d 17 to 21 of each experimental period, composited, and stored at $-20^{\circ} \mathrm{C}$ until analysis for DM and chemical composition. Fresh silage samples were prepared for measurement of $\mathrm{pH}$ and analysis of VFA, lactic acid, formic acid, ethanol, water-soluble carbohydrate, soluble N, and ammonia N concentrations as described by Ahvenjärvi et al. (2018). Leftovers were weighed daily, and samples were collected from 17 to $21 \mathrm{~d}$, mixed, and analyzed for DM. Concentrate pellets and leftovers were dried in a forced-air oven at $55^{\circ} \mathrm{C}$ for $48 \mathrm{~h}$, ground through a 1-mm screen (Sakomylly KT-120, Koneteollisuus Oy), and analyzed for DM, NDF, ash, ether extract (EE), and CP as described in detail by Ahvenjärvi et al. (2018). Gross energy (GE) was determined using a Parr 6200 Oxygen Bomb Calorimeter (Parr Instrument Co.) with benzoic acid (CAS 65-85-0, cat. no. 3415, Parr Instrument Co.) as a standard. Fatty acid methyl esters from freeze-dried silage samples and air-dried concentrates were prepared in a single-extraction methylation step with chloroform and methanolic sulfuric acid (2\%, vol/vol; Shingfield et al., 2003) and determined by GC as described for milk FA.

Daily feed intake and milk yield were recorded throughout the experiment, but only measurements made between d 17 and 21 were used for statistical 
analysis. Cows were milked twice daily at 0700 and 1645 h. Milk samples were taken for 3 consecutive days (d 19, 20 , and 21) in each experimental period during morning and evening milking, preserved with bronopol tablets (Valio Ltd.), and stored at $4{ }^{\circ} \mathrm{C}$ until infrared analysis for fat, crude protein, lactose, urea, and somatic cells (MilkoScan FT+, Foss Electric). Milk composition was calculated as geometric average of morning and evening milk yields. Untreated milk samples were collected on d 20 and 21, pooled according to morning and evening milk yield, and stored at $-20^{\circ} \mathrm{C}$ until analysis for milk
FA composition. Fat was extracted from milk samples and converted to FAME according to Shingfield et al. (2003). Briefly, fat in $1 \mathrm{~mL}$ of milk was extracted twice with a mixture of ammonia, ethanol, diethyl ether, and hexane (0.2:1:2.5:2.5, vol/vol). Fatty acids were then methylated with methanolic sodium methoxide in the presence of methyl acetate. Profiles of FAME were determined by GC coupled with flame-ionization detector $(6890 \mathrm{~N}$, Agilent Technologies) and equipped with a CP-Sil 88 column $(100 \mathrm{~m} \times 0.25 \mathrm{~mm}$ internal diameter, 0.2- $\mu \mathrm{m}$ film thickness; Agilent Technologies)

Table 1. Formulation of dietary treatments and their chemical composition

\begin{tabular}{|c|c|c|c|c|}
\hline \multirow[b]{2}{*}{ Item $^{1}$} & \multicolumn{4}{|c|}{ Treatment $^{2}$} \\
\hline & $\mathrm{CON}$ & $\mathrm{RSC}$ & YHR & GCE \\
\hline \multicolumn{5}{|l|}{ Feed ingredients (\% DM) } \\
\hline Grass silage $^{3}$ & 45.0 & 45.0 & 45.0 & 45.0 \\
\hline Barley & 12.1 & 12.1 & 12.0 & 12.1 \\
\hline Wheat & 6.05 & 6.05 & 6.02 & 6.05 \\
\hline Oat & 9.35 & 9.35 & 9.31 & 9.35 \\
\hline Molassed sugar beet pulp & 6.90 & 6.90 & 6.84 & 6.90 \\
\hline Rapeseed meal & 19.2 & - & 19.2 & 19.2 \\
\hline Rapeseed cake & - & 19.2 & - & - \\
\hline Yeast hydrolysate product ${ }^{4}$ & - & - & 0.07 & - \\
\hline Resin acid-based compound ${ }^{5}$ & - & - & 0.11 & - \\
\hline Mineral and vitamin premix ${ }^{6}$ & 1.40 & 1.40 & 1.40 & 1.40 \\
\hline \multicolumn{5}{|c|}{ Chemical composition (\% DM unless otherwise stated) } \\
\hline DM & 62.1 & 62.9 & 62.2 & 62.1 \\
\hline $\mathrm{OM}$ & 92.8 & 92.9 & 92.7 & 92.8 \\
\hline $\mathrm{CP}$ & 17.0 & 17.6 & 17.3 & 17.0 \\
\hline $\mathrm{EE}$ & 3.48 & 5.03 & 3.50 & 3.48 \\
\hline NDF & 37.2 & 36.4 & 37.5 & 37.2 \\
\hline NFC & 35.1 & 33.9 & 34.4 & 35.1 \\
\hline GE (MJ/kg of DM) & 18.0 & 18.4 & 18.0 & 18.0 \\
\hline \multicolumn{5}{|l|}{ Fatty acid $(\mathrm{g} / 100 \mathrm{~g}$ of $\mathrm{DM})$} \\
\hline $12: 0$ & 0.062 & 0.062 & 0.062 & 0.062 \\
\hline $14: 0$ & 0.088 & 0.091 & 0.087 & 0.088 \\
\hline $16: 0$ & 3.73 & 4.15 & 3.65 & 3.73 \\
\hline cis-9 16:1 & 0.117 & 0.188 & 0.125 & 0.117 \\
\hline $18: 0$ & 0.342 & 0.554 & 0.347 & 0.342 \\
\hline cis-9 18:1 & 4.37 & 10.8 & 4.49 & 4.37 \\
\hline cis-11 18:1 & 0.83 & 1.29 & 0.83 & 0.83 \\
\hline cis-9,cis-12 18:2 & 7.40 & 10.6 & 7.44 & 7.40 \\
\hline cis-9,cis-12,cis-15 18:3 & 4.64 & 6.41 & 4.61 & 4.64 \\
\hline$\Sigma \mathrm{SFA}$ & 5.26 & 6.18 & 5.20 & 5.26 \\
\hline$\Sigma$ MUFA & 5.95 & 13.1 & 6.11 & 5.95 \\
\hline$\Sigma$ PUFA & 12.1 & 17.1 & 12.2 & 12.1 \\
\hline$\Sigma$ Fatty acids & 23.4 & 36.4 & 23.5 & 23.4 \\
\hline
\end{tabular}

${ }^{1} \mathrm{EE}=$ ether extract; $\mathrm{GE}=$ gross energy.

${ }^{2} \mathrm{CON}=$ grass silage-based diet with forage-to-concentrate ratio of 45:55, containing rapeseed meal, as control; $\mathrm{RSC}=$ the same basal diet with rapeseed cake instead of rapeseed meal; YHR $=$ control diet supplemented with $20 \mathrm{~g} / \mathrm{d}$ of yeast hydrolysate product and $30 \mathrm{~g} / \mathrm{d}$ of resin acid-based compound; GCE = the same control diet supplemented with $20 \mathrm{~g} / \mathrm{d}$ of garlic-citrus extract and essential oils combination.

${ }^{3}$ Mean fermentation characteristics of experimental silage: $\mathrm{pH}, 3.98$; in DM $(\mathrm{g} / \mathrm{kg})$ lactic acid, 53.3; acetic acid, 17.8; propionic acid, 2.59; butyric acid, 0.18 ; soluble $\mathrm{N}(\mathrm{g} / \mathrm{kg}$ of total $\mathrm{N}), 448$; ammonium $\mathrm{N}(\mathrm{g} / \mathrm{kg}$ of total $\mathrm{N})$, 32.9; gross energy ( $\mathrm{MJ} / \mathrm{kg}$ of $\mathrm{DM}), 17.6$.

${ }^{4}$ Progut Rumen, Hankkija Oy.

${ }^{5}$ Progres Dry, Hankkija Oy.

${ }^{6}$ Lypsykivennäinen Tiineys+, Hankkija Oy. Cows had free access to Lypsy Melli (Mg; Hankkija Oy) and salt blocks. 
and using a temperature gradient program (Shingfield et al., 2003) with injector and detector temperatures maintained at $255^{\circ} \mathrm{C}$. Hydrogen was used as a carrier gas starting from $206.8 \mathrm{kPa}$ initial pressure and gradually raised after $50 \mathrm{~min}$ to a final pressure of $310.3 \mathrm{kPa}$.

On d 21 of each experimental period, at $1000 \mathrm{~h}$ and after respiratory chamber measurements, samples of rumen liquid $(500 \mathrm{~mL})$ were collected by stomach tubing using a Ruminator apparatus (http://www.profs -products.com). Immediately after collection, $\mathrm{pH}$ was measured using a portable $\mathrm{pH}$ meter. Two subsamples were taken for VFA and ammonia $\mathrm{N}$ determination. For VFA determination, $5 \mathrm{~mL}$ of rumen liquid and $0.5 \mathrm{~mL}$ of saturated mercuric chloride solution were added into small plastic bottles. After mixing, $2.0 \mathrm{~mL}$ of $1 \mathrm{M} \mathrm{NaOH}$ solution was added to the same bottle and mixed. For ammonia $\mathrm{N}$ determination, $0.3 \mathrm{~mL}$ of $50 \%$ sulfuric acid and $15 \mathrm{~mL}$ of filtered rumen liquid were added into a small plastic bottle and mixed. Immediately after preparation, all subsamples were kept in ice before storing at $-20^{\circ} \mathrm{C}$ until analysis for VFA profile and ammonia $\mathrm{N}$ determinations by procedures described in Huhtanen et al. (1998) and McCullough (1967), respectively.

Four open-circuit respiratory chambers $(\mathrm{W} \times \mathrm{L} \times \mathrm{H}$ : $288 \times 396 \times 220 \mathrm{~cm}$ ), located in the research dairy barn, Jokioinen, Finland, were used to measure $\mathrm{CH}_{4}, \mathrm{CO}_{2}$, and $\mathrm{H}_{2}$ production and $\mathrm{O}_{2}$ consumption of individual cows over $4 \mathrm{~d}$ (d 17 to 21), with the first day serving as acclimatization. The cows were restrained within the chambers by a neck yoke on a dedicated platform (180 $\times 126 \mathrm{~cm}$ ) covered with a rubber mat and had free access to fresh water and salt block. Concentrations of the gases in the inlet and exhaust airflow were measured by a computer-controlled system using dedicated analyzers (Oxymax, Columbus Instruments) with 3.5-min intervals for each chamber and the reference air. Gas analyzers were calibrated using the authentic standard gases (AGA Ltd.) in the beginning of each measurement. Air outflow for each chamber was measured by HFM-200 mass flow meter with a laminar flow element capable of measuring up to $3,000 \mathrm{~L} / \mathrm{min}$ (Teledyne Hastings Instruments). The flow meter had an accuracy of $<1 \%$ of full scale and repeatability of $0.05 \%$ of full scale. The air flow was set to $1,500 \mathrm{~L} / \mathrm{min}$, and the measured flow was corrected using an integrated thermometer and manometer to standard temperature and pressure $\left(0^{\circ} \mathrm{C}\right.$ and $\left.101.325 \mathrm{kPa}\right)$. The air inflow to the chambers was calculated using Haldane transformation assuming constant volume of physiologically inert nitrogen $\left(\mathrm{N}_{2}\right)$ in both inspired and expired air. An adjustable air conditioning system (flow 500-2000 L/min; cooling/heating capacity of $3.0 \mathrm{~kW}$ ) allowed mixing of the air inside the chambers and environmental control of temperature across a range of 12 to $22^{\circ} \mathrm{C}$ and a relative humidity of 50 to $70 \%$, as monitored using electronic sensors (PTU300, Vaisala). The temperature and humidity were measured and recorded every 5 min using data loggers (DL4000), vNet PoE connection packages, and Viewlinc software (Vaisala). For cow welfare and safety, an emergency door sensitive to electricity failure or high $\mathrm{CO}_{2}$ concentration (GMT222, Vaisala) was installed, and a GSM (Global System for Mobile Communications) robot (Eldes Alarms) was programmed to communicate to researchers' personnel mobile phones in both cases. To avoid interference of cow and chamber effects in the statistical model, every cow was kept in the same chamber in different periods.

Total fecal and urine samples were collected from 8 cows for 3 consecutive days starting on d 18 at $1000 \mathrm{~h}$. The quantity of feces was weighed, and a subsample (5\% wt/wt) was stored at $-20^{\circ} \mathrm{C}$ for chemical analysis. At the end of the experiment, the samples were thawed (1-2 d at room temperature) and mixed thoroughly, and a subsample was obtained for every animal per period for chemical analysis. Feces were dried at $60^{\circ} \mathrm{C}$, and the sample was ground through a 1-mm sieve, and DM, ash, N, NDF, EE (after hydrolysis with $3 \mathrm{M} \mathrm{HCl}$ ), and GE were determined as described earlier for feed samples. Total urine was collected over $3 \mathrm{~d}$ simultaneously with fecal collections, using a lightweight harness and flexible tubing attached to the vulva. The urine was collected in plastic canisters containing $600 \mathrm{~mL}$ of $5 M$ sulfuric acid. Collection vessels were changed at 12-h intervals. On each sampling day, a urine sample of $0.1 \%$ was collected and stored at $-20^{\circ} \mathrm{C}$ for analysis of $\mathrm{N}$ concentration (Kjeldahl method) and urea. In addition, a $0.2 \%$ subsample was collected and stored at $-20^{\circ} \mathrm{C}$ to be freeze-dried for analysis of GE. The precipitations in urine samples were collected, stored at $-20^{\circ} \mathrm{C}$, and dried before $\mathrm{N}$ determination.

\section{Calculations and Statistical Analysis}

Total-tract apparent digestibility coefficients were calculated based on the difference between intake of a nutrient and its fecal output divided by the corresponding intake of a nutrient. Intake of $\mathrm{ME}$ was calculated as the difference between GE intake and energy excretion in feces, urine, and $\mathrm{CH}_{4}$. Energy loss as $\mathrm{CH}_{4}$ was calculated using the factor $55.24 \mathrm{~kJ} / \mathrm{g}$ (Kriss, 1930). Nonfiber carbohydrates were calculated as $100-(\mathrm{NDF}+\mathrm{CP}+\mathrm{EE}+\mathrm{ash}$; NRC, 2001). Energy-corrected milk was calculated using the equation suggested by Sjaunja et al. (1990) based on milk fat, protein, and lactose yields, and energy secretion 
$(\mathrm{MJ} / \mathrm{d})$ in milk was calculated as $3.14 \times \mathrm{ECM}$ yield $(\mathrm{kg} / \mathrm{d})$. Heat production was calculated according to the Brouwer (1965) equation. Nitrogen balance was calculated as the difference between $\mathrm{N}$ intake and $\mathrm{N}$ excretion in feces, urine, and milk, where milk $\mathrm{N}$ was calculated as milk $\mathrm{CP} / 6.38$.

Normality of analyzed variables was checked using box plot and scatter plot of residuals and fitted values generated using the Mixed procedure of SAS (version 9.4, SAS Institute Inc.). Experimental data were analyzed by ANOVA for a replicated $4 \times 4$ Latin square using the Mixed procedure of SAS, with a model that included fixed effects of square, period, and treatment, and interactions between square and treatment, square and period, and treatment and period. Cow was considered as a random effect. The average of daily values was calculated and used in the statistical analysis. Least squares means \pm standard error of means are reported, and treatment effects were declared significant at $P$ $\leq 0.05$, whereas a tendency or trend was assumed for $0.05<P<0.10$. When the overall effect of treatment was significant, pairwise differences among means were explored further using Tukey's test.

\section{RESULTS}

The chemical composition of diets was similar, except for RSC, which had slightly greater concentrations of $\mathrm{CP}, \mathrm{EE}$, and GE, and slightly lower concentrations of NDF and NFC (Table 1). Relative to CON, the amount of added fat in RSC was 1.5\% DM. Feed intake did not differ across experimental diets. Apparent total-tract digestibility of DM, OM, NDF, and GE remained unaffected by the diets, but that of $\mathrm{CP}$ and $\mathrm{EE}$ was greater $(P<0.01)$ for RSC relative to all other diets (Table 2$)$.
Methane emissions, as grams per day, tended $(P=$ $0.06)$ to be lower for RSC compared with other diets (Table 3). The RSC diet reduced $(P<0.01) \mathrm{CH}_{4}$ emissions, expressed per unit of feed intake, OM digested in the total tract, milk yield, or ECM yield relative to other diets, whereas the $\mathrm{GCE}$ diet reduced $\mathrm{CH}_{4}$ emissions expressed per unit of feed or energy intake compared with CON. Further, hydrogen emission did not differ among the treatments. Diets did not change $\mathrm{CO}_{2}$ emissions as grams per day, per unit of feed intake, or $\mathrm{DM}$ digested in the total digestive tract. However, $\mathrm{CO}_{2}$ emissions per unit of milk or ECM was lower $(P \leq 0.04)$ for RSC compared with CON. Feeding experimental diets did not greatly affect rumen fermentation pattern, but the molar proportion of isobutyrate was greater $(P$ $=0.02)$ and that of caproate was lower $(P=0.01)$ for RSC than for other diets (Table 4).

Feeding RSC did not have any effect on GE intake, but ME intake was greater $(P=0.01)$ for RSC than for other diets (Table 5). Compared with the CON diet, GCE decreased $(P<0.01) \mathrm{CH}_{4}$ emissions, expressed as percentage of GE intake. The proportions of GE lost in feces and urine, used for milk synthesis or dissipated as heat did not differ from CON. The proportion of $\mathrm{N}$ intake excreted in feces was lower $(P<0.01)$ for RSC compared with other diets, whereas $\mathrm{N}$ balance increased $(P=0.01)$ in cows fed YHR compared with those fed CON (Table 5).

Milk yield was greater $(P<0.01)$ in $\mathrm{RSC}$ compared with all other diets (Table 6). Cows fed RSC had a greater ECM yield $(P=0.05)$ than that of cows fed CON but similar to YHR and GCE. Milk lactose and total solid yields were greater $(P<0.01)$ for RSC compared with other diets. Diets had no effects on milk composition other than urea concentration, which was

Table 2. Feed intake and apparent total-tract nutrient digestibility of lactating dairy cows fed different $\operatorname{diets}^{1}$

\begin{tabular}{lcccccc}
\hline & \multicolumn{9}{c}{ Treatment $^{2}$} & & \\
\cline { 2 - 5 } Item & CON & RSC & YHR & GCE & SEM & $P$-value \\
\hline DMI (kg/d) & 27.7 & 27.9 & 28.1 & 27.9 & 0.49 & 0.76 \\
Digestibility & & & & & \\
DM & 69.9 & 70.3 & 69.6 & 70.0 & 0.64 & 0.60 \\
OM & 71.5 & 72.0 & 71.2 & 71.6 & 0.65 & 0.55 \\
CP & $70.5^{\mathrm{b}}$ & $72.6^{\mathrm{a}}$ & $70.9^{\mathrm{b}}$ & $70.7^{\mathrm{b}}$ & 0.70 & $<0.01$ \\
EE & $65.4^{\mathrm{b}}$ & $72.6^{\mathrm{a}}$ & $65.5^{\mathrm{b}}$ & $66.4^{\mathrm{b}}$ & 1.16 & $<0.01$ \\
NDF & 54.1 & 54.6 & 55.4 & 54.4 & 1.50 & 0.85 \\
GE & 68.9 & 69.8 & 68.7 & 69.3 & 0.75 & 0.35 \\
\hline
\end{tabular}

${ }^{\mathrm{a}, \mathrm{b}}$ Mean values in the same row with different superscripts differ $(P<0.05)$.

${ }^{1}$ Values are LSM and pooled SEM for $\mathrm{n}=8$.

${ }^{2} \mathrm{CON}=$ grass silage-based diet with forage-to-concentrate ratio of 45:55, containing rapeseed meal, as control; $\mathrm{RSC}=$ the same basal diet with rapeseed cake instead of rapeseed meal; YHR = control diet supplemented with $20 \mathrm{~g} / \mathrm{d}$ of yeast hydrolysate product and $30 \mathrm{~g} / \mathrm{d}$ of resin acid-based compound; GCE = the same control diet supplemented with $20 \mathrm{~g} / \mathrm{d}$ of garlic-citrus extract and essential oils combination.

${ }^{3} \mathrm{EE}=$ ether extract; $\mathrm{GE}=$ gross energy. 
Table 3. Enteric methane and hydrogen emissions of lactating dairy cows fed different diets ${ }^{1}$

\begin{tabular}{|c|c|c|c|c|c|c|}
\hline Item & \multicolumn{4}{|c|}{ Treatment $^{2}$} & SEM & $P$-value \\
\hline \multicolumn{7}{|l|}{ Methane } \\
\hline $\mathrm{g} / \mathrm{kg}$ of DMI & $19.7^{\mathrm{a}}$ & $18.3^{\mathrm{c}}$ & $19.5^{\mathrm{ab}}$ & $19.3^{\mathrm{b}}$ & 0.51 & $<0.01$ \\
\hline $\mathrm{g} / \mathrm{kg}$ of $\mathrm{OM}$ digested & $29.7^{\mathrm{a}}$ & $27.4^{\mathrm{b}}$ & $29.5^{\mathrm{a}}$ & $29.0^{\mathrm{a}}$ & 0.64 & $<0.01$ \\
\hline $\mathrm{g} / \mathrm{kg}$ of milk & $14.6^{\mathrm{a}}$ & $12.3^{\mathrm{b}}$ & $14.5^{\mathrm{a}}$ & $14.1^{\mathrm{a}}$ & 0.42 & 0.014 \\
\hline \multicolumn{7}{|l|}{ Carbon dioxide } \\
\hline $\mathrm{g} / \mathrm{d}$ & 13.332 & 13,475 & 13,437 & 13.366 & 239.9 & 0.80 \\
\hline $\mathrm{g} / \mathrm{kg}$ of DMI & 482 & 484 & 479 & 481 & 8.7 & 0.85 \\
\hline $\mathrm{g} / \mathrm{kg}$ of $\mathrm{OM}$ digested & 690 & 689 & 689 & 687 & 12.6 & 0.97 \\
\hline $\mathrm{g} / \mathrm{kg}$ of milk & $356^{\mathrm{a}}$ & $326^{\mathrm{b}}$ & $355^{\mathrm{a}}$ & $352^{\mathrm{a}}$ & 5.2 & 0.015 \\
\hline $\mathrm{g} / \mathrm{kg}$ of ECM & $335^{\mathrm{a}}$ & $317^{\mathrm{b}}$ & $331^{\mathrm{ab}}$ & $329^{\mathrm{ab}}$ & 5.3 & 0.041 \\
\hline \multicolumn{7}{|l|}{ Hydrogen } \\
\hline
\end{tabular}

${ }^{\mathrm{a}-\mathrm{c}}$ Mean values in the same row with different superscripts differ $(P<0.05)$.

${ }^{1}$ Values are LSM and pooled SEM for $\mathrm{n}=8$.

${ }^{2} \mathrm{CON}=$ grass silage-based diet with forage-to-concentrate ratio of 45:55, containing rapeseed meal, as control; RSC $=$ the same basal diet with rapeseed cake instead of rapeseed meal; YHR = the control diet supplemented with $20 \mathrm{~g} / \mathrm{d}$ of yeast hydrolysate product and $30 \mathrm{~g} / \mathrm{d}$ of resin acid-based compound; GCE = the same control diet supplemented with $20 \mathrm{~g} / \mathrm{d}$ of garlic-citrus extract and essential oils combination.

highest for YHR and lowest for RSC $(P<0.01)$. Feed efficiency, expressed as milk yield/DMI, increased $(P=$ $0.02)$ in RSC compared with the other diets, whereas ECM/DMI tended to be greater $(P=0.07)$ in RSC compared with CON.

Compared with the other diets, RSC had lower $(P<$ 0.01 ) proportions of 8:0, 10:0, 12:0, 14:0, 16:0, and total SFA in milk fat but a greater $(P<0.01)$ proportion of 18:0 (Table 7). In addition, the proportion of cis-9 18:1, total cis 18:1, cis-9,cis-12 18:2, cis-9,cis-12,cis-15 18:3, total cis 20:1, and total cis MUFA were greater $(P<$ 0.01 ) with RSC relative to other diets, even though total cis $16: 1$ was lower $(P<0.01)$. Total trans $16: 1$, trans-10 18:1, trans-11 18:1, total trans 18:1, total trans 18:2, cis-9,trans-11 CLA, trans-10,cis-12 CLA, total CLA, total trans 20:1, and total trans FA were greater $(P<$ $0.01)$ in RSC compared with all other diets. Generally, the proportion of total cis UFA was greater $(P<0.01)$

Table 4. Rumen fermentation characteristics of lactating dairy cows fed different $\operatorname{diets}^{1}$

\begin{tabular}{|c|c|c|c|c|c|c|}
\hline \multirow[b]{2}{*}{ Item } & \multicolumn{4}{|c|}{ Treatment $^{2}$} & \multirow[b]{2}{*}{ SEM } & \multirow[b]{2}{*}{$P$-value } \\
\hline & $\mathrm{CON}$ & $\mathrm{RSC}$ & YHR & GCE & & \\
\hline Rumen pH & 6.78 & 6.82 & 6.82 & 6.82 & 0.05 & 0.96 \\
\hline Ammonia $\mathrm{N}(\mathrm{m} M)$ & 4.12 & 4.13 & 4.11 & 3.60 & 0.48 & 0.20 \\
\hline Total VFA $(\mathrm{m} M)$ & 96.7 & 86.5 & 92.7 & 91.8 & 3.66 & 0.24 \\
\hline \multicolumn{7}{|c|}{ VFA profile $(\mathrm{mol} / 100 \mathrm{~mol})$} \\
\hline Acetate & 65.7 & 64.8 & 64.1 & 66.0 & 1.25 & 0.65 \\
\hline Propionate & 17.6 & 18.9 & 18.6 & 17.9 & 0.59 & 0.44 \\
\hline Butyrate & 13.2 & 12.6 & 13.8 & 12.8 & 0.59 & 0.46 \\
\hline Valerate & 1.26 & 1.28 & 1.33 & 1.24 & 0.07 & 0.77 \\
\hline Isobutyrate & $0.93^{\mathrm{b}}$ & $1.25^{\mathrm{a}}$ & $0.99^{\mathrm{b}}$ & $0.92^{\mathrm{b}}$ & 0.10 & 0.017 \\
\hline Isovalerate & 0.76 & 0.86 & 0.79 & 0.75 & 0.057 & 0.16 \\
\hline Caproate & $0.46^{\mathrm{a}}$ & $0.24^{\mathrm{b}}$ & $0.47^{\mathrm{a}}$ & $0.45^{\mathrm{a}}$ & 0.035 & 0.011 \\
\hline Acetate:propionate & 3.75 & 3.43 & 3.50 & 3.72 & 0.173 & 0.47 \\
\hline
\end{tabular}


Table 5. Energy and N metabolism of dairy cows fed different $\operatorname{diets}^{1}$

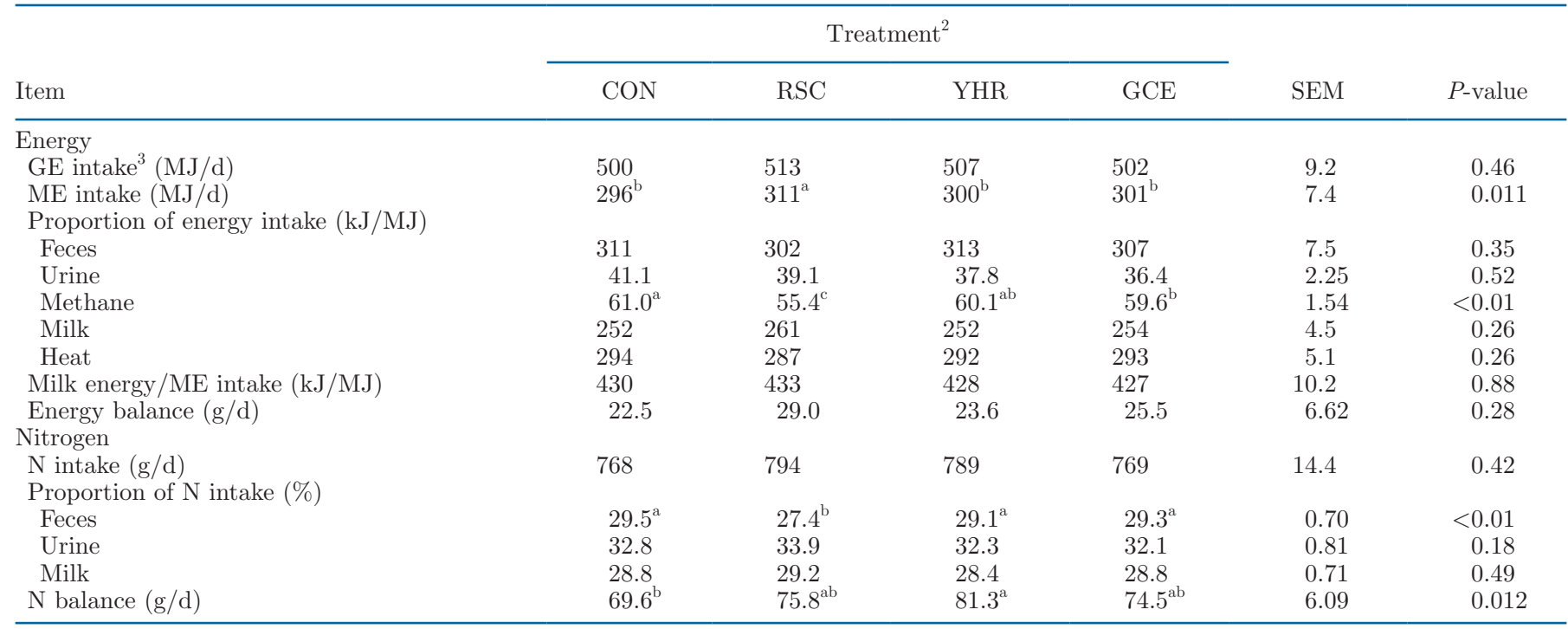

a,b Mean values in the same row with different superscripts differ $(P<0.05)$.

${ }^{1}$ Values are LSM and pooled SEM for $\mathrm{n}=8$.

${ }^{2} \mathrm{CON}=$ grass silage-based diet with forage-to-concentrate ratio of 45:55, containing rapeseed meal, as control; RSC $=$ the same basal diet with rapeseed cake instead of rapeseed meal; YHR = the control diet supplemented with $20 \mathrm{~g} / \mathrm{d}$ of yeast hydrolysate product and $30 \mathrm{~g} / \mathrm{d}$ of resin acid-based compound; GCE = the same control diet supplemented with $20 \mathrm{~g} / \mathrm{d}$ of garlic-citrus extract and essential oils combination.

${ }^{3} \mathrm{GE}=$ gross energy

and trans FA plus SFA were lower $(P<0.01)$ in RSC relative to the other diets. Further, the proportion of odd- and branched-chain FA (OBCFA) was greater $(P$
$=0.01)$ in milk from cows fed YHR and GCE compared with CON, whereas GCE had a greater proportion of OBCFA than RSC.

Table 6. Milk yield and composition of lactating dairy cows fed different $\operatorname{diets}^{1}$

\begin{tabular}{lcccccc}
\hline & \multicolumn{7}{c}{ Treatment $^{2}$} \\
Item & CON & RSC & YHR & GCE & SEM & P-value \\
\cline { 2 - 5 } & & & & & \\
Yield (kg/d) & & & & & \\
Milk & $37.5^{\mathrm{b}}$ & $41.5^{\mathrm{a}}$ & $37.9^{\mathrm{b}}$ & $38.0^{\mathrm{b}}$ & 0.76 & $<0.01$ \\
$\mathrm{ECM}^{3}$ & $40.0^{\mathrm{b}}$ & $42.6^{\mathrm{a}}$ & $40.6^{\mathrm{ab}}$ & $40.6^{\mathrm{ab}}$ & 0.58 & 0.048 \\
Fat & 1.63 & 1.70 & 1.66 & 1.66 & 0.04 & 0.37 \\
Protein & 1.41 & 1.48 & 1.43 & 1.42 & 0.03 & 0.093 \\
Lactose & $1.70^{\mathrm{b}}$ & $1.92^{\mathrm{a}}$ & $1.72^{\mathrm{b}}$ & $1.73^{\mathrm{b}}$ & 0.04 & $<0.01$ \\
Total solids & $5.12^{\mathrm{b}}$ & $5.52^{\mathrm{a}}$ & $5.19^{\mathrm{b}}$ & $5.20^{\mathrm{b}}$ & 0.07 & $<0.01$ \\
Concentration (\%) & & & & & & \\
Fat & 4.35 & 4.12 & 4.40 & 4.39 & 0.15 & 0.15 \\
Protein & 3.76 & 3.58 & 3.77 & 3.73 & 0.09 & 0.12 \\
Lactose & 4.53 & 4.63 & 4.55 & 4.56 & 0.04 & 0.12 \\
Total solids & 13.6 & 13.3 & 13.7 & 13.7 & 0.21 & 0.17 \\
MUN (mg/100 mL) & $28.2^{\mathrm{b}}$ & $27.2^{\mathrm{c}}$ & $29.6^{\mathrm{a}}$ & $28.1^{\mathrm{b}}$ & 1.74 & $<0.01$ \\
SCC (1,000/mL) & 131 & 50.8 & 119 & 70.1 & 57.1 & 0.65 \\
Feed efficiency & & & & & \\
Milk/DMI & $1.36^{\mathrm{b}}$ & $1.49^{\mathrm{a}}$ & $1.35^{\mathrm{b}}$ & $1.37^{\mathrm{b}}$ & 0.025 & 0.019 \\
ECM/DMI & 1.44 & 1.53 & 1.45 & 1.46 & 0.026 & 0.071 \\
\hline
\end{tabular}

${ }^{\mathrm{a}-\mathrm{c}}$ Mean values in the same row with different superscripts differ $(P<0.05)$.

${ }^{1}$ Values are LSM and pooled SEM for $\mathrm{n}=8$.

${ }^{2} \mathrm{CON}=$ grass silage-based diet with forage-to-concentrate ratio of 45:55, containing rapeseed meal, as control; $\mathrm{RSC}=$ the same basal diet with rapeseed cake instead of rapeseed meal; YHR $=$ the control diet supplemented with $20 \mathrm{~g} / \mathrm{d}$ of yeast hydrolysate product and $30 \mathrm{~g} / \mathrm{d}$ of resin acid-based compound; GCE = the same control diet supplemented with $20 \mathrm{~g} / \mathrm{d}$ of garlic-citrus extract and essential oils combination.

${ }^{3} \mathrm{ECM}$ calculated as described by Sjaunja et al. (1990). 
Table 7. Fatty acid composition in milk of lactating dairy cows fed different diets ${ }^{1}$

\begin{tabular}{|c|c|c|c|c|c|c|}
\hline \multirow[b]{2}{*}{$\mathrm{FA}^{2}(\mathrm{~g} / 100 \mathrm{~g}$ of $\mathrm{FA})$} & \multicolumn{4}{|c|}{ Treatment $^{3}$} & \multirow[b]{2}{*}{ SEM } & \multirow[b]{2}{*}{$P$-value } \\
\hline & $\mathrm{CON}$ & $\mathrm{RSC}$ & YHR & GCE & & \\
\hline 4:0 & 3.73 & 3.84 & 3.76 & 3.70 & 0.062 & 0.20 \\
\hline $8: 0$ & $1.64^{\mathrm{a}}$ & $1.49^{\mathrm{b}}$ & $1.64^{\mathrm{a}}$ & $1.61^{\mathrm{a}}$ & 0.044 & $<0.01$ \\
\hline $10: 0$ & $3.85^{\mathrm{a}}$ & $3.22^{\mathrm{b}}$ & $3.88^{\mathrm{a}}$ & $3.80^{\mathrm{a}}$ & 0.115 & $<0.01$ \\
\hline $12: 0$ & $4.49^{\mathrm{a}}$ & $3.57^{\mathrm{b}}$ & $4.52^{\mathrm{a}}$ & $4.46^{\mathrm{a}}$ & 0.133 & $<0.01$ \\
\hline $14: 0$ & $12.9^{\mathrm{a}}$ & $11.5^{\mathrm{b}}$ & $12.9^{\mathrm{a}}$ & $12.7^{\mathrm{a}}$ & 0.21 & $<0.01$ \\
\hline cis-9 14:1 & 1.23 & 1.01 & 1.20 & 1.19 & 0.059 & 0.11 \\
\hline $16: 0$ & $32.0^{\mathrm{a}}$ & $23.9^{\mathrm{b}}$ & $31.7^{\mathrm{a}}$ & $31.8^{\mathrm{a}}$ & 0.63 & $<0.01$ \\
\hline cis $16: 1$ & $1.71^{\mathrm{a}}$ & $1.36^{\mathrm{b}}$ & $1.68^{\mathrm{a}}$ & $1.73^{\mathrm{a}}$ & 0.077 & $<0.01$ \\
\hline trans $16: 1$ & $0.098^{\mathrm{b}}$ & $0.134^{\mathrm{a}}$ & $0.097^{\mathrm{b}}$ & $0.095^{\mathrm{b}}$ & 0.0048 & $<0.01$ \\
\hline$\Sigma 16: 1$ & $2.27^{\mathrm{a}}$ & $1.87^{\mathrm{b}}$ & $2.23^{\mathrm{a}}$ & $2.28^{\mathrm{a}}$ & 0.076 & $<0.01$ \\
\hline $18: 0$ & $8.58^{\mathrm{b}}$ & $12.2^{\mathrm{a}}$ & $8.61^{\mathrm{b}}$ & $8.52^{\mathrm{b}}$ & 0.318 & $<0.01$ \\
\hline cis-9 18:1 & $14.7^{\mathrm{b}}$ & $19.6^{\mathrm{a}}$ & $14.6^{\mathrm{b}}$ & $15.1^{\mathrm{b}}$ & 0.57 & $<0.01$ \\
\hline$\Sigma$ cis $18: 1$ & $15.7^{\mathrm{b}}$ & $21.0^{\mathrm{a}}$ & $15.7^{\mathrm{b}}$ & $16.2^{\mathrm{b}}$ & 0.60 & $<0.01$ \\
\hline trans-10 18:1 & $0.26^{\mathrm{b}}$ & $0.50^{\mathrm{a}}$ & $0.28^{\mathrm{b}}$ & $0.26^{\mathrm{b}}$ & 0.025 & $<0.01$ \\
\hline trans-11 18:1 & $0.68^{\mathrm{b}}$ & $1.40^{\mathrm{a}}$ & $0.72^{\mathrm{b}}$ & $0.73^{\mathrm{b}}$ & 0.079 & $<0.01$ \\
\hline$\Sigma$ trans $18: 1$ & $1.96^{\mathrm{b}}$ & $3.87^{\mathrm{a}}$ & $2.07^{\mathrm{b}}$ & $2.03^{\mathrm{b}}$ & 0.169 & $<0.01$ \\
\hline$\Sigma 18: 1$ & $17.7^{\mathrm{b}}$ & $24.8^{\mathrm{a}}$ & $17.7^{\mathrm{b}}$ & $18.2^{\mathrm{b}}$ & 0.63 & $<0.01$ \\
\hline cis-9,cis-12 18:2 & 1.40 & 1.59 & 1.43 & 1.40 & 0.061 & 0.045 \\
\hline$\Sigma$ cis $18: 2$ & $1.43^{\mathrm{b}}$ & $1.65^{\mathrm{a}}$ & $1.47^{\mathrm{ab}}$ & $1.44^{\mathrm{b}}$ & 0.062 & 0.031 \\
\hline$\Sigma$ trans $18: 2$ & $0.87^{\mathrm{b}}$ & $1.48^{\mathrm{a}}$ & $0.90^{\mathrm{b}}$ & $0.93^{\mathrm{b}}$ & 0.063 & $<0.01$ \\
\hline cis-9,trans-11 18:2 & $0.33^{\mathrm{b}}$ & $0.61^{\mathrm{a}}$ & $0.34^{\mathrm{b}}$ & $0.35^{\mathrm{b}}$ & 0.032 & $<0.01$ \\
\hline trans-10, cis-12 18:2 & $0.028^{\mathrm{b}}$ & $0.039^{\mathrm{a}}$ & $0.029^{\mathrm{b}}$ & $0.027^{\mathrm{c}}$ & 0.0010 & $<0.01$ \\
\hline$\Sigma$ CLA & $0.38^{\mathrm{b}}$ & $0.70^{\mathrm{a}}$ & $0.40^{\mathrm{b}}$ & $0.42^{\mathrm{b}}$ & 0.035 & $<0.01$ \\
\hline$\Sigma 18: 2$ & $2.31^{\mathrm{b}}$ & $3.13^{\mathrm{a}}$ & $2.37^{\mathrm{b}}$ & $2.37^{\mathrm{b}}$ & 0.111 & $<0.01$ \\
\hline cis-9,cis-12,cis-15 18:3 & 0.32 & 0.38 & 0.32 & 0.32 & 0.017 & 0.047 \\
\hline$\Sigma$ cis $20: 1$ & $0.17^{\mathrm{b}}$ & $0.23^{\mathrm{a}}$ & $0.17^{\mathrm{b}}$ & $0.17^{\mathrm{b}}$ & 0.005 & $<0.01$ \\
\hline$\Sigma$ trans $20: 1$ & $0.03^{\mathrm{b}}$ & $0.05^{\mathrm{a}}$ & $0.03^{\mathrm{b}}$ & $0.03^{\mathrm{b}}$ & 0.003 & $<0.01$ \\
\hline$\Sigma 20: 1$ & $0.20^{\mathrm{b}}$ & $0.28^{\mathrm{a}}$ & $0.20^{\mathrm{b}}$ & $0.20^{\mathrm{b}}$ & 0.007 & $<0.01$ \\
\hline$\Sigma$ cis $22: 1$ & 0.02 & 0.03 & 0.03 & 0.02 & 0.003 & 0.43 \\
\hline$\Sigma$ unidentified & 0.06 & 0.07 & 0.07 & 0.06 & 0.004 & 0.28 \\
\hline$\Sigma$ cis $\mathrm{MUFA}$ & $20.4^{\mathrm{b}}$ & $25.0^{\mathrm{a}}$ & $20.2^{\mathrm{b}}$ & $20.8^{\mathrm{b}}$ & 0.60 & $<0.01$ \\
\hline$\Sigma$ cis $\mathrm{PUFA}$ & 2.17 & 2.40 & 2.20 & 2.18 & 0.093 & 0.11 \\
\hline$\Sigma$ cis $\mathrm{UFA}$ & $22.5^{\mathrm{b}}$ & $27.4^{\mathrm{a}}$ & $22.4^{\mathrm{b}}$ & $23.0^{\mathrm{b}}$ & 0.62 & $<0.01$ \\
\hline$\Sigma \mathrm{SFA}$ & $73.9^{\mathrm{a}}$ & $66.3^{\mathrm{b}}$ & $73.9^{\mathrm{a}}$ & $73.3^{\mathrm{a}}$ & 0.68 & $<0.01$ \\
\hline$\Sigma$ trans $\mathrm{FA}$ & $3.24^{\mathrm{b}}$ & $5.79^{\mathrm{a}}$ & $3.39^{\mathrm{b}}$ & $3.37^{\mathrm{b}}$ & 0.227 & $<0.01$ \\
\hline$\Sigma$ trans $\mathrm{FA}+\mathrm{SFA}$ & $77.1^{\mathrm{a}}$ & $72.1^{\mathrm{b}}$ & $77.2^{\mathrm{a}}$ & $76.7^{\mathrm{a}}$ & 0.61 & $<0.01$ \\
\hline$\Sigma$ OBCFA & $4.30^{\mathrm{c}}$ & $4.33^{\mathrm{bc}}$ & $4.41^{\mathrm{ab}}$ & $4.42^{\mathrm{a}}$ & 0.128 & 0.013 \\
\hline \multirow{2}{*}{\multicolumn{7}{|c|}{ 暨 Mean values in the same row with different superscripts differ $(P<0.05)$. }} \\
\hline & & & & & & ${ }^{1}$ Values are LSM and pooled SEM for $\mathrm{n}=8$ \\
\hline \multicolumn{7}{|c|}{${ }^{2} \mathrm{FA}=$ fatty acid; OBCFA = odd- and branched-chain fatty acid. } \\
\hline \multicolumn{7}{|c|}{$\begin{array}{l}{ }^{3} \mathrm{CON}=\text { grass silage-based diet with forage-to-concentrate ratio of } 45: 55 \text {, containing rapeseed meal, as control } \\
\mathrm{RSC}=\text { the same basal diet with rapeseed cake instead of rapeseed meal; YHR = control diet supplemented } \\
\text { with } 20 \mathrm{~g} / \mathrm{d} \text { of yeast hydrolysate product and } 30 \mathrm{~g} / \mathrm{d} \text { of resin acid-based compound; GCE = the same contro } \\
\text { diet supplemented with } 20 \mathrm{~g} / \mathrm{d} \text { of garlic-citrus extract and essential oils combination. }\end{array}$} \\
\hline
\end{tabular}

\section{DISCUSSION}

\section{Intake and Nutrient Digestion}

Diets were formulated to be isonitrogenous; however, rapeseed cake had greater $\mathrm{CP}$ concentration than rapeseed meal, which led to slightly greater $\mathrm{CP}$ concentration in RSC (17.6 vs. $17.0 \%$ DM). As planned, RSC had greater lipid (i.e., EE) content relative to CON (5.0 vs. $3.5 \% \mathrm{DM}$ ). The amount of rapeseed cake was maximized in the diet to ensure that a reasonable quantity of oil was added to the diet. The lack of effect on feed intake due to oil in RSC can be attributed to the mod- erate inclusion of rapeseed oil in the diet $(1.55 \% \mathrm{DM}$ from rapeseed cake) and the form used for lipid supply. According to NRC (2001), low levels of oil supplementation (3.0 to $4.0 \% \mathrm{DM}$ ), equal to 6.0 to $7.0 \% \mathrm{DM}$ total lipid in the diet, are not expected to reduce feed intake of dairy cows. Supplementation of a diet based on corn and grass silage with lipids from rapeseed cake, whole cracked rapeseed, or rapeseed oil had no adverse effects on DM intake or milk yield (Brask et al., 2013a), which is in agreement with our results. Nonetheless, in the current experiment, feeding RSC increased milk and ECM yields compared with the other diets. Feeding more lipid had no negative effect on nutrient digest- 
ibility in our study, which agrees with observations from Brask et al. (2013b). However, it should be noted that compensatory hindgut fiber digestion can mask potential differences in rumen digestion when lipid supplements are added to dairy cow diets (Shingfield et al., 2008).

In the current study, YHR and GCE did not affect DMI compared with CON, unlike in some earlier studies, where the addition of plant extracts, their components, or both in ruminant diets reduced palatability and DMI (Klevenhusen et al., 2011; Hristov et al., 2013). Likewise, the lack of effect of natural additives on total-tract apparent digestibility agrees with findings of Eger et al. (2018), when a combination of garlic and citrus extract without essential oils was supplied at high and low doses in an in vitro rumen simulation experiment. However, a reduction in the overall percentage of methanogens in the rumen without adverse effect on ruminal fermentation and nutrient digestibility was found in the study by Eger et al. (2018). Changes in DMI have been related to diet digestibility, especially to that of the fiber fraction of the diet. In our study, supplementation with natural additives had no effect on total-tract digestibility of nutrients compared with CON, which may explain the lack of effect of these additives on DMI.

\section{Enteric Methane Emissions and Rumen Fermentation}

In this study, $\mathrm{CH}_{4}$ emissions were in the range of 5.54 to $6.10 \%$ of GE intake, which are within the ranges of 5.60 to $6.32 \%$ reported by Brask et al. (2013b) for rapeseed cake and control diets based on grass and maize silage, and 5.77 to $6.92 \%$ (Brask et al., 2013a) for crushed full-fat rapeseed cake and control diets based on early- and late-harvested grass silages. The reduction of $\mathrm{CH}_{4}$ per kilogram of DMI due to every percentage of added oil via rapeseed cake (i.e., 4.7\%) was greater than the 1.6 and $4.4 \%$ reported by Brask et al. (2013a,b). Based on a meta-analysis of 67 diets, Martin et al. (2010) estimated a mean decrease in $\mathrm{CH}_{4}$ emissions of $3.8 \%$ with each $1 \%$ addition of all fat supplements, whereas the respective value for rapeseed oil was $2.5 \%$.

The experimental diets had only marginal effects on rumen VFA profile. Regardless of similar fermentation pattern between diets, RSC decreased $\mathrm{CH}_{4}$ emissions (g/d) by $7 \%$ relative to $\mathrm{CON}$. Owing to increases in milk yield, $\mathrm{CH}_{4}$ emissions per unit of milk yield and ECM decreased by 16 and $12 \%$, respectively, in our study. Consistent with our findings, supplementation of a diet based on grass and corn silage with lipids from rapeseed cake, whole cracked rapeseed, or rapeseed oil decreased $\mathrm{CH}_{4}$ emissions per unit of ECM by 7, 17, and $18 \%$, respectively (Brask et al., 2013b). Beauchemin et al. (2009) observed decreases of $16 \%$ (g/ $\mathrm{kg}$ DMI) and $9 \%(\mathrm{~g} / \mathrm{kg} \mathrm{FCM})$ in $\mathrm{CH}_{4}$ emissions of dairy cows fed crushed canola seed; however, these effects were not accompanied by any substantial changes in rumen fermentation pattern. It should be noted that we took rumen samples only once during the sampling period, whereas $\mathrm{CH}_{4}$ production was continuously measured over $3 \mathrm{~d}$. Continuous measurement of ruminal fermentation would have provided more complete data.

Feeding YHR had no effect on $\mathrm{CH}_{4}$ production and emissions intensity. The result suggests that YHR did not influence the $\mathrm{CH}_{4}$ emissions of lactating dairy cows, either directly or in relation to the amount of milk produced. Although GCE marginally affected $\mathrm{CH}_{4}$ emissions, it decreased $\mathrm{CH}_{4}$ emissions, expressed as gram per kilogram of DMI or as percentage of GE intake, compared with CON. A similar formulation of garlic and citrus extracts manifested its effect by reducing methanogenic archaea using the rumen simulation technique (Eger et al., 2018). Further, a study on a commercial dairy farm in the UK (Vrancken et al., 2019) reported a reduction in enteric $\mathrm{CH}_{4}$ emissions in Jersey $(-38.3 \%)$ and Holstein $(-20.7 \%)$ cows by supplementing a combination of garlic and citrus extracts. Ineffectiveness of organosulfur compounds with respect to in vivo $\mathrm{CH}_{4}$ mitigation was observed by Klevenhusen et al. (2011), who tested 5 or $2 \mathrm{~g} / \mathrm{kg}$ dietary DM garlic oil and diallyl disulfide, respectively, without significant effects on feed intake and rumen fermentation characteristics in sheep. It appears that the lack of effect on $\mathrm{CH}_{4}$ production in our study is consistent with the lack of changes in DMI and total-tract OM digestion.

\section{Energy and Nitrogen Utilization}

Introducing more oil to the diet via replacing rapeseed meal with rapeseed cake (0 vs. $19.3 \%$ of diet DM) did not affect GE intake and energy balance, which is in agreement with observations from Bayat et al. (2018). However, we observed that RSC reduced $\mathrm{CH}_{4}$ energy excretion as a proportion $(\mathrm{kJ} / \mathrm{MJ})$ of energy intake and increased ME intake compared with cows fed the other diets. In the absence of RSC effect on feed intake, the lower $\mathrm{CH}_{4}$ output may be explained either by a dilution effect of oil on fermentable OM or by ruminal biohydrogenation of unsaturated FA (Knapp et al., 2014). In the present study, rapeseed cake reduced $\mathrm{CH}_{4}$ energy excretion as a proportion $(\mathrm{kJ} / \mathrm{MJ})$ of energy intake by $5.9 \%$ per $1 \%$ supplemental oil. Beauchemin and McGinn (2006) found a significant reduction in $\mathrm{CH}_{4}$ loss as proportion of GE intake when feeding heifers a ration with $4.6 \%$ added rapeseed oil, but this was associated 
with a feed intake depression. However, we found that RSC increased ME intake without changing the efficiency of ME utilization for milk production. Increased energy supply from RSC compared with CON and the proportional reductions in fecal, urinary, $\mathrm{CH}_{4}$, and heat energy (significant or numerical) were not enough to allow the supplemented lipid to influence ME utilization efficiency, despite an increase in ME intake. Also, as explained by Moallem et al. (2007), supplemental fat increases the diet energy density and energy intake but usually does not improve energy balance.

Effects of lipid supplementation on the $\mathrm{N}$ balance of cows are inconsistent in the literature (Benchaar et al., 2015; Bayat et al., 2018). In the present study, the $\mathrm{N}$ balance was not affected by RSC, whereas YHR improved the $\mathrm{N}$ balance of the animals but did not influence other parameters related to $\mathrm{N}$ and energy utilization. Previously, resin acid-based compound at the dose of $7 \mathrm{~g} / \mathrm{d}$ per cow improved the digestibility of DM, OM, and NDF (P. Kairenius, Luke, Jokioinen, Finland, personal communication), without affecting feed intake or milk yield of dairy cows during lactation wk 1 to 10 after calving. In an in vitro experiment, yeast hydrolysate acted as a fermentation enhancer for rumen microbiota (Kettunen et al., 2016). However, as a combination, these products did not have a major effect on energy and $\mathrm{N}$ utilization, except the improved $\mathrm{N}$ balance.

\section{Milk Production and Composition}

Several studies have reported effects of canola seeds or meals on productivity of dairy cows. Inclusion of approximately $13 \%$ of DM high-18:1 extruded canola meal (13.7\% EE containing $76.1 \%$ 18:1 FA) decreased DMI but had no effect on milk yield and, thus, increased feed efficiency in high-producing dairy cows (Hristov et al., 2011). In line with our results, lipid supplementation in the form of milled rapeseed increased milk yield by $2.1 \mathrm{~kg} / \mathrm{d}$ in dairy cows that were between 169 to 281 DIM, with no effect of lipid on feed intake (Kliem et al., 2019b). In the present study, conducted with dairy cows in mid-lactation, the greater GE concentration $(+0.4 \mathrm{MJ} / \mathrm{kg} \mathrm{DM})$ in RSC may have induced the improved milk yield without changing DMI. Onetti and Grummer (2004) observed that lipid supplementation increased milk yield and milk fat yield when fed to cows during early lactation $(<120$ DIM) but not in mid-lactation (>120 DIM). In contrast, Wu and Huber (1994) suggested an increase in milk yield due to lipid supplementation after the peak of lactation. Here, RSC increased milk yield, which can be attributed to increasing milk lactose, as lactose is the main factor determining milk volume. Overall, the greater milk and ECM yields of the cows fed RSC compared with CON improved feed efficiency. However, it should be noted that, due to the limited number of animals and the relatively short experimental periods (i.e., 3 wk), production responses should be interpreted with caution. The lack of RSC diet effect on milk fat and protein concentrations is probably due to the low level of rapeseed oil supplementation $(1.5 \% \mathrm{DM})$ in the current experiment.

Compared with CON, YHR and GCE diets had no effect on milk yield and composition. In an earlier in vivo study, however, Vrancken et al. (2019) reported increased milk yield in cows fed a combination of garlic and citrus extracts. This could be attributed to longer supplement feeding for $12 \mathrm{wk}$, compared with $3 \mathrm{wk}$ in each period in our study. In addition, in a previous study with 248 Holstein-Friesian cows, yeast hydrolysate product at $10 \mathrm{~g} / \mathrm{d}$ per cow increased total yields of lactose and protein (Gaffney et al., 2014). In our study, YHR and GCE did not change either DMI or digestibility of nutrients, which explains the absence of changes in milk production.

\section{Milk Fatty Acid Composition}

Relative to CON, the RSC diet decreased SFA by $10 \%$ in milk fat by replacing them with cis MUFA, especially cis-9 18:1. These changes are characteristic in dairy cows fed dietary plant oil supplements and especially oil supplements rich in cis-9 18:1, such as rapeseed oil and high-oleic sunflower oil (Kliem and Shingfield, 2016; Bayat et al., 2018; Kliem et al., 2019a). Moreover, RSC not only decreased SFA in general but also slightly changed the composition of milk SFA by reducing 12:0, 14:0, and 16:0 while increasing 18:0. This change is beneficial for human health, as milk and dairy products contribute largely to the fat and SFA contents in the human diet (Hunter et al., 2010; Eilander et al., 2015). Evidence suggests that replacing SFA with UFA can be used to reduce LDL cholesterol concentrations that may affect the risk of cardiovascular diseases (Krauss and Kris-Etherton, 2020). In a recent study (Vasilopoulou et al., 2020), consumption of a high-fat diet containing SFA-reduced and MUFA-enriched dairy products, via supplementing dairy cow diets with higholeic acid sunflower oil, resulted in beneficial effects on fasting LDL cholesterol and endothelial function in adults at moderate risk of cardiovascular diseases, compared with conventional dairy products. This indicates that replacing conventional milk with fat-modified milk could be used to improve human health.

A decrease in milk SFA concentration in RSC can be attributed to an increase in the amount of long-chain UFA available for absorption, leading to an inhibition of 
de novo synthesis of short- and medium-chain FA in the mammary gland (Kliem and Shingfield, 2016). Feeding RSC increased the levels of 18:0 in milk as a result of biohydrogenation of the supplemental unsaturated 18-carbon FA in the rumen. An increase in milk cis-9 18:1 content due to the inclusion of high-oil rapeseed cake arises from increased ruminal escape of cis-9 18:1 and via desaturation of 18:0 in the mammary gland.

Consistent with previous experiments (Bayat et al., 2018; Kliem et al., 2019b), the proportion of trans FA in milk fat increased when cows received RSC, the most abundant trans FA being trans-11 18:1 and with a significant contribution of cis-9,trans-11 CLA to trans FA. Reductions in milk fat secretion have been associated with increases in milk trans-10,cis-12 CLA and, in some cases, in milk trans-10 18:1 (Shingfield et al., 2010). However, the moderate increases in trans-10 18:1 and trans-10,cis-12 CLA observed for RSC might explain the lack of change in milk fat synthesis. In the current study, the milk concentration of trans-10 18:1 FA, a good proxy for biohydrogenation-induced milk fat depression, in cows fed RSC ( $0.50 \%$ of total FA) was well below the suggested mean and median from a recent meta-analysis of more than 500 treatment means of milk trans-10 18:1 in the literature (mean $=1.39$ and median $=0.7$ trans $-1018: 1$ as percentage of FA; Matamoros et al., 2020). Total trans FA increased as a consequence of the greater intake of unsaturated 18-carbon FA susceptible to biohydrogenation and isomerization (Griinari et al., 1998). Although industrial trans FA are considered harmful for human health, some evidence suggests that ruminant trans FA may have beneficial effects (Da Silva et al., 2015). In addition, the consumption of dairy products may have neutral or even protective effects on some cardiovascular risk factors, and the effect varies according to the type of dairy product used (Duarte et al., 2021).

The proportion of OBCFA, which mainly originate from rumen microbes leaving the rumen, increased in GCE and YHR compared with CON. This may indicate some changes in the rumen microbiome or microbial lipid synthesis, although post-ruminal modification of OBCFA, such as de novo synthesis, desaturation, and elongation, occurs in dairy cows (Vlaeminck et al., 2015).

\section{CONCLUSIONS}

The RSC diet decreased $\mathrm{CH}_{4}$ production per kilogram of DMI and improved milk production and feed efficiency of lactating dairy cows. Feeding diets containing natural additives (i.e., YHR and GCE) had no effect on performance and total $\mathrm{H}_{2}$ or $\mathrm{CH}_{4}$ emissions; however, feeding $\mathrm{GCE}$ reduced $\mathrm{CH}_{4}$ emissions expressed as gram per kilogram of DMI compared with control. None of the diets influenced energy balance, although the proportion of energy intake excreted as $\mathrm{CH}_{4}$ was lower with RSC and GCE compared with control. Feeding RSC decreased SFA by $10 \%$ in milk fat that was replaced mainly by cis MUFA, whereas the proportion of OBCFA increased with YHR and GCE compared with control. Based on the results of this study, the diet containing rapeseed cake has good potential to reduce enteric $\mathrm{CH}_{4}$ emissions and simultaneously improve milk production and nutritional composition of milk in a sustainable manner.

\section{ACKNOWLEDGMENTS}

The authors express their appreciation to the staff of the Natural Resources Institute Finland (Luke) Jokioinen Research Barn, for technical support, care of experimental animals, and assistance in sample collection, and in the laboratory for chemical analysis of samples. The experiment was funded jointly by Luke (Helsinki, Finland), Arla Ltd. (Sipoo, Finland), Hankkija Ltd. (Hyvinkää, Finland), and Mootral SA (Rolle, Switzerland). The authors have not stated any conflicts of interest.

\section{REFERENCES}

Ahvenjärvi, S., L. Nyholm, J. Nousiainen, E. A. Mäntysaari, and M. Lidauer. 2018. Polyethylene glycol as an indigestible marker to estimate fecal output in dairy cows. J. Dairy Sci. 101:4245-4258. https://doi.org/10.3168/jds.2017-13337.

Bayat, A. R., I. Tapio, J. Vilkki, K. J. Shingfield, and H. Leskinen. 2018. Plant oil supplements reduce methane emissions and improve milk fatty acid composition in dairy cows fed grass silage-based diets without affecting milk yield. J. Dairy Sci. 101:1136-1151. https://doi.org/10.3168/jds.2017-13545.

Beauchemin, K. A., and S. M. McGinn. 2006. Methane emissions from beef cattle: Effects of fumaric acid, essential oil, and canola oil. J. Anim. Sci. 84:1489-1496. https://doi.org/10.2527/2006.8461489x.

Beauchemin, K. A., S. M. McGinn, C. Benchaar, and L. Holtshausen. 2009. Crushed sunflower, flax, or canola seed in lactating dairy cow diets: Effects on methane production, rumen fermentation and milk production. J. Dairy Sci. 92:2118-2127. https://doi.org/10 .3168/jds.2008-1903.

Beauchemin, K. A., E. M. Ungerfeld, R. J. Eckard, and M. Wang. 2020. Review: Fifty years of research on rumen methanogenesis: Lessons learned and future challenges for mitigation. Animal 14(Suppl. 1):s2-s16. https://doi.org/10.1017/S1751731119003100.

Benchaar, C., F. Hassanat, R. Martineau, and R. Gervais. 2015. Linseed oil supplementation to dairy cows fed diets based on red clover silage or corn silage: Effects on methane production, rumen fermentation, nutrient digestibility, N-balance, and milk production. J. Dairy Sci. 98:7993-8008. https://doi.org/10.3168/jds.2015 $-9398$

Brask, M., P. Lund, A. L. F. Hellwing, M. Poulsen, and M. R. Weisbjerg. 2013a. Enteric methane production, digestibility and rumen fermentation in dairy cows fed different forages with and without rapeseed fat supplementation. Anim. Feed Sci. Technol. 184:67-79 https://doi.org/10.1016/j.anifeedsci.2013.06.006.

Brask, M., P. Lund, M. R. Weisbjerg, A. L. F. Hellwing, M. Poulsen, M. K. Larsen, and T. Hvelplund. 2013b. Methane production and 
digestion of different physical forms of rapeseed as fat supplements in dairy cows. J. Dairy Sci. 96:2356-2365. https://doi.org/ 10.3168/jds.2011-5239.

Brouwer, E. 1965. Report of sub-committee on constants and factors. Pages 441-443 in Energy Metabolism of Farm Animals. EAAP Publ. No. 11. Academic Press.

Da Silva, M. S., P. Julien, L. Pérusse, M.-C. Vohl, and I. Rudkowska. 2015. Natural rumen-derived trans fatty acids are associated with metabolic markers of cardiac health. Lipids 50:873-882. https:// doi.org/10.1007/s11745-015-4055-3.

Duarte, C., V. Boccardi, P. A. Andrade, A. C. S. Lopes, and P. F. Jacques. 2021. Dairy versus other saturated fats source and cardiometabolic risk markers: Systematic review of randomized controlled trials. Crit. Rev. Food Sci. Nutr. 61:450-461. https://doi .org/10.1080/10408398.2020.1736509.

Eger, M., M. Graz, S. Riede, and G. Breves. 2018. Application of Mootral $^{\mathrm{TM}}$ reduces methane production by altering the archaea community in the rumen simulation technique. Front. Microbiol. 9:2094. https://doi.org/10.3389/fmicb.2018.02094.

Eilander, A., R. Harika, and P. L. Zock. 2015. Intake and sources of dietary fatty acids in Europe: Are current population intakes of fats aligned with dietary recommendations? Eur. J. Lipid Sci. Technol. 117:1370-1377. https://doi.org/10.1002/ejlt.201400513.

Gaffney, D. J., M. R. Sheehy, J. A. Vuorenmaa, and A. G. Fahey. 2014. The effect of supplementing dairy cows with a hydrolyzed yeast product (Progut Rumen) on milk production and somatic cell score. J. Dairy Sci. 97(E-Suppl. 1):789. (Abstr.)

Griinari, J. M., D. A. Dwyer, M. A. McGuire, D. E. Bauman, D. L. Palmquist, and K. V. V. Nurmela. 1998. Trans-octadecenoic acids and milk fat depression in lactating dairy cows. J. Dairy Sci. 81:1251-1261. https://doi.org/10.3168/jds.S0022-0302(98)75686 -3 .

Hasan, S., S. Junnikkala, O. Peltoniemi, L. Paulin, A. Lyyski, J. Vuorenmaa, and C. Oliviero. 2018a. Dietary supplementation with yeast hydrolysate in pregnancy influences colostrum yield and gut microbiota of sows and piglets after birth. PLoS One 13:e0197586. https://doi.org/10.1371/journal.pone.0197586.

Hasan, S., S. Saha, S. Junnikkala, T. Orro, O. Peltoniemi, and C. Oliviero. 2018b. Late gestation diet supplementation of resin acid-enriched composition increases sow colostrum IgG content, piglet colostrum intake and improve sow gut microbiota. Animal 13:1599-1606. https://doi.org/10.1017/S1751731118003518.

Hristov, A. N., C. Domitrovich, A. Wachter, T. Cassidy, C. Lee, K. J. Shingfield, P. Kairenius, J. Davis, and J. Brown. 2011. Effect of replacing solvent-extracted canola meal with high-oil traditional canola, high-oleic acid canola, or high-erucic acid rapeseed meals on rumen fermentation, digestibility, milk production, and milk fatty acid composition in lactating dairy cows. J. Dairy Sci. 94:4057-4074. https://doi.org/10.3168/jds.2011-4283.

Hristov, A. N., C. Lee, T. Cassidy, K. Heyler, J. A. Tekippe, G. A. Varga, B. Corl, and R. C. Brandt. 2013. Effect of Origanum vulgare L. leaves on rumen fermentation, production, and milk fatty acid composition in lactating dairy cows. J. Dairy Sci. 96:1189-1202. https://doi.org/10.3168/jds.2012-5975.

Hristov, A. N., J. Oh, F. Giallongo, T. W. Frederick, M. T. Harper, H. L. Weeks, A. F. Branco, P. J. Moate, M. H. Deighton, S. R. Williams, M. Kindermann, and S. Duval. 2015. An inhibitor persistently decreased enteric methane emission from dairy cows with no negative effect on milk production. Proc. Natl. Acad. Sci. USA 112:10663-10668. https://doi.org/10.1073/pnas.1504124112.

Huhtanen, P., R. Blauwiekel, and I. Saastamoinen. 1998. Effects of intraruminal infusions of propionate and butyrate with two different protein supplements on milk production and blood metabolites in dairy cows receiving grass silage-based diets. J. Sci. Food Agric. 77:213-222. https://doi.org/10.1002/(SICI)1097-0010(199806)77: $2<213::$ AID-JSFA28>3.0.CO $2-6$.

Hunter, J. E., J. Zhang, and P. M. Kris-Etherton. 2010. Cardiovascular disease risk of dietary stearic acid compared with trans, other saturated, and unsaturated fatty acids: A systematic review. Am. J. Clin. Nutr. 91:46-63. https://doi.org/10.3945/ajcn.2009.27661.
Kettunen, H., J. Vuorenmaa, D. Gaffney, and J. Apajalahti. 2016. Yeast hydrolysate product enhances ruminal fermentation in vitro. J. Appl. Anim. Nutr. 4:1-7. https://doi.org/10.1017/jan.2015.14.

Kilkenny, C., W. J. Browne, I. C. Cuthill, M. Emerson, and D. G. Altman. 2010. Improving bioscience research reporting: The ARRIVE guidelines for reporting animal research. PLoS Biol. 8:e1000412. https://doi.org/10.1371/journal.pbio.1000412.

Klevenhusen, F., J. O. Zeitz, S. Duval, M. Kreuzer, and C. R. Soliva. 2011. Garlic oil and its principal component diallyl disulfide fail to mitigate methane, but improve digestibility in sheep. Anim. Feed Sci. Technol. 166-167:356-363. https://doi.org/10.1016/j .anifeedsci.2011.04.071.

Kliem, K. E., D. J. Humphries, P. Kirton, D. I. Givens, and C. K. Reynolds. 2019b. Differential effects of oilseed supplements on methane production and milk fatty acid concentrations in dairy cows. Animal 13:309-317. https://doi.org/10.1017/S1751731118001398.

Kliem, K. E., D. J. Humphries, O. Markey, D. Vasilopoulou, C. C. Fagan, A. S. Grandison, K. G. Jackson, S. Todd, D. I. Givens, and J. A. Lovegrove. 2019a. Food chain approach to lowering the saturated fat of milk and dairy products. Int. J. Dairy Technol. 72:100-109. https://doi.org/10.1111/1471-0307.12564.

Kliem, K. E., and K. J. Shingfield. 2016. Manipulation of milk fatty acid composition in lactating cows: Opportunities and challenges. Eur. J. Lipid Sci. Technol. 118:1661-1683. https://doi.org/10 .1002/ejlt.201400543.

Knapp, J. R., G. L. Laur, P. A. Vadas, W. P. Weiss, and J. M. Tricarico. 2014. Invited review: Enteric methane in dairy cattle production: Quantifying the opportunities and impact of reducing emissions. J. Dairy Sci. 97:3231-3261. https://doi.org/10.3168/jds 2013-7234.

Kolling, G. J., S. C. B. Stivanin, A. A. M. Gabbi, F. S. Machado, A. L. Ferreira, M. M. Campos, T. R. Tomich, C. S. Cunha, S. W. Dill, L. G. R. Pereira, and V. Fischer. 2018. Performance and methane emissions in dairy cows fed oregano and green tea extracts as feed additives. J. Dairy Sci. 101:4221-4234. https://doi.org/10.3168/ jds.2017-13841.

Krauss, R. M., and P. M. Kris-Etherton. 2020. Public health guidelines should recommend reducing saturated fat consumption as much as possible: Debate consensus. Am. J. Clin. Nutr. 112:25-26. https:/ /doi.org/10.1093/ajen/nqaa134.

Kriss, M. 1930. Quantitative relations of the dry matter of the food consumed, the heat production, the gaseous outgo, and the insensible loss in body weight of cattle. J. Agric. Res. 40:283-295.

Martin, C., D. P. Morgavi, and M. Doreau. 2010. Methane mitigation in ruminants: From microbe to the farm scale. Animal 4:351-365. https://doi.org/10.1017/S1751731109990620.

Matamoros, C., R. N. Klopp, L. E. Moraes, and K. J. Harvatine. 2020. Meta-analysis of the relationship between milk trans-10 C18:1, milk fatty acids $<16 \mathrm{C}$, and milk fat production. J. Dairy Sci. 103:10195-10206. https://doi.org/10.3168/jds.2019-18129.

McCullough, H. 1967. The determination of ammonia in whole blood by direct colorimetric method. Clin. Chim. Acta 17:297-304. https: //doi.org/10.1016/0009-8981(67)90133-7.

Moallem, U., M. Katz, A. Arieli, and H. Lehrer. 2007. Effects of peripartum propylene glycol or fats differing in fatty acid profiles on feed intake, production, and plasma metabolites in dairy cows. J. Dairy Sci. 90:3846-3856. https://doi.org/10.3168/jds.2007-0092.

Muller, R. A., and E. A. Muller. 2017. Fugitive methane and the role of atmospheric half-life. Geoinfor. Geostat. An Overview 5:3. https://doi.org/10.4172/2327-4581.1000162.

Niu, M., E. Kebreab, A. N. Hristov, J. Oh, C. Arndt, A. Bannink, A. R. Bayat, A. F. Brito, T. Boland, D. Casper, L. A. Crompton, J. Dijkstra, M. A. Eugène, P. C. Garnsworthy, M. N. Haque, A. L. F. Hellwing, P. Huhtanen, M. Kreuzer, B. Kuhla, P. Lund, J. Madsen, C. Martin, S. C. McClelland, M. McGee, P. J. Moate, S. Muetzel, C. Muñoz, P. O'Kiely, N. Peiren, C. K. Reynolds, A. Schwarm, K. J. Shingfield, T. M. Storlien, M. R. Weisbjerg, D. R. Yáñez-Ruiz, and Z. Yu. 2018. Prediction of enteric methane production, yield, and intensity in dairy cattle using an intercontinental database. Glob. Chang. Biol. 24:3368-3389. https://doi .org/10.1111/gcb.14094. 
NRC. 2001. Nutrient Requirements of Dairy Cattle. 7th rev. ed. Natl. Acad. Press.

Olijhoek, D. W., A. L. F. Hellwing, K. Grevsen, L. S. Haveman, M. R. Chowdhury, P. Løvendahl, M. R. Weisbjerg, S. J. Noel, O. Højberg, L. Wiking, and P. Lund. 2019. Effect of dried oregano (Origanum vulgare L.) plant material in feed on methane production, rumen fermentation, nutrient digestibility, and milk fatty acid composition in dairy cows. J. Dairy Sci. 102:9902-9918. https: //doi.org/10.3168/jds.2019-16329.

Onetti, S. G., and R. R. Grummer. 2004. Response of lactating cows to three supplemental fat sources as affected by forage in the diet and stage of lactation: A meta-analysis of literature. Anim. Feed Sci. Technol. 115:65-82. https://doi.org/10.1016/j.anifeedsci.2004 .02 .009 .

Qin, N., M. Niku, S. Junnikkala, J. Vuorenmaa, and H. Kettunen. 2020. Biomarkers of inflammation and gut permeability in dairy cows with or without dietary resin acids. Abstract no. 21.29 of the Book of Abstracts of the 71st Annual Meeting of the European Federation of Animal Science. Wageningen Academic Publishers.

Roque, B. M., H. J. van Lingen, H. Vrancken, and E. Kebreab. 2019. Effect of Mootral - A garlic- and citrus-extract based feed additive - on enteric methane emissions in feedlot cattle. Transl. Anim. Sci. 3:1383-1388. https://doi.org/10.1093/tas/txz133.

Shingfield, K. J., S. Ahvenjärvi, V. Toivonen, A. Ärölä, K. V. V. Nurmela, P. Huhtanen, and J. M. Griinari. 2003. Effect of dietary fish oil on biohydrogenation of fatty acids and milk fatty acid content in cows. Anim. Sci. 77:165-179. https://doi.org/10.1017/ S1357729800053765.

Shingfield, K. J., S. Ahvenjärvi, V. Toivonen, A. Vanhatalo, P. Huhtanen, and J. M. Griinari. 2008. Effect of incremental levels of sunflower seed oil in the diet on ruminal lipid metabolism in lactating cows. Br. J. Nutr. 99:971-983. https://doi.org/10.1017/ S0007114507853323.

Shingfield, K. J., L. Bernard, C. Leroux, and Y. Chilliard. 2010. Role of trans fatty acids in the nutritional regulation of mammary lipogenesis in ruminants. Animal 4:1140-1166. https://doi.org/10 $.1017 /$ S1751731110000510.

Sjaunja, L. O., L. Baevre, L. Junkkarinen, J. Pedersen, and J. Setälä. 1990. A Nordic proposal for an energy corrected milk (ECM) formula. Page 156 in Proc. 27th Biennial Session of the International Committee for Animal Recording (ICAR), Paris, France. EAAP Publication No. 50, Centre for Agricultural Publishing and Documentation (Pudoc).

Vasilopoulou, D., O. Markey, K. E. Kliem, C. C. Fagan, A. S. Grandison, D. J. Humphries, S. Todd, K. G. Jackson, D. I. Givens, and
J. A. Lovegrove. 2020. Reformulation initiative for partial replacement of saturated with unsaturated fats in dairy foods attenuates the increase in LDL cholesterol and improves flow-mediated dilatation compared with conventional dairy: the randomized, controlled replacement of saturated fat in dairy on total cholesterol (RESET) study. Am. J. Clin. Nutr. 111:739-748. https://doi.org/10.1093/ ajcn/nqz344.

Vienola, K., G. Jurgens, J. Vuorenmaa, and J. Apajalahti. 2018. Tall oil fatty acid inclusion in the diet improves performance and increases ileal density of lactobacilli in broiler chickens. Br. Poult. Sci. 59:349-355. https://doi.org/10.1080/00071668.2018.1455965.

Vlaeminck, B., R. Gervais, M. M. Rahman, F. Gadeyne, M. Gorniak, M. Doreau, and V. Fievez. 2015. Postruminal synthesis modifies the odd- and branched-chain fatty acid profile from the duodenum to milk. J. Dairy Sci. 98:4829-4840. https://doi.org/10.3168/jds .2014-9207.

Vrancken, H., M. Suenkel, P. R. Hargreaves, L. Chew, and E. Towers. 2019. Reduction of enteric methane emission in a commercial dairy farm by a novel feed supplement. Open J. Anim. Sci. 9:286-296. https://doi.org/10.4236/ojas.2019.93024.

Wu, Z., and J. Huber. 1994. Relationship between dietary fat supplementation and milk protein concentration in lactating cows: A review. Livest. Prod. Sci. 39:141-155. https://doi.org/10.1016/0301 $-6226(94) 90180-5$.

Yang, W. Z., C. Benchaar, B. N. Ametaj, A. V. Chaves, M. L. He, and T. A. McAllister. 2007. Effects of garlic and juniper berry essential oils on ruminal fermentation and on the site and extent of digestion in lactating cows. J. Dairy Sci. 90:5671-5681. https://doi.org/ 10.3168/jds.2007-0369.

\section{ORCIDS}

A. R. Bayat (1) https://orcid.org/0000-0002-4894-0662

J. Vilkki ㅇ https://orcid.org/0000-0002-7480-842X

A. Razzaghi $\odot$ https://orcid.org/0000-0003-3498-4549

H. Leskinen (1) https://orcid.org/0000-0002-9892-5671

H. Kettunen ๑ https://orcid.org/0000-0001-6166-1847

R. Khurana ๑ https://orcid.org/0000-0002-1257-4074

T. Brand () https://orcid.org/0000-0003-2967-1556

S. Ahvenjärvi $\odot$ https://orcid.org/0000-0001-6977-0933 